\title{
Oral cavity: reservoir of hospital pathogens?
}

\section{Janaina de Cássia Orlandi Sardi}

Department of Physiological Sciences, Piracicaba Dental School, University of Campinas, Piracicaba, SP, Brazil.

*Corresponding author: Sardi JCO, Department of Physiological Sciences, Piracicaba Dental School, University of Campinas, Piracicaba, SP, Brazil, Email: janasardi@gmail.com

Received date: June 12, 2017; Accepted date: June 14, 2017; Published date: June 16, 2017

Copyright: $\odot 2017$ Sardi JCO. This is an open-access article distributed under the terms of the Creative Commons Attribution License, which permits unrestricted use, distribution, and reproduction in any medium, provided the original author and source are credited.

\section{Editorial}

The oropharyngeal region is one of the most complex niches of the human body being colonized by several species of bacteria and fungi. In the oral cavity, there are several species considered pathogenic and opportunistic colonizers that can cause various diseases. In addition, the ability to form biofilm presented by different bacterial and fungal genera is directly related to the virulence of these microorganisms and their ability to cause infections. Pneumonia is an involvement of the pulmonary parenchyma caused by a wide variety of agents, with bacterial pneumonia being the most common cause of the disease. Of the infections acquired in hospitals, $15 \%$ are pneumonias, $50 \%$ of which result in death. The risk of development of nosocomial pneumonia is 10 to 20 times greater in the intensive care unit (ICU) and its development in patients with mechanical ventilation and/or humidifier ranges from $7 \%$ to $40 \%$. The aspiration of microorganisms originating from the upper airways during sleep occurs in $45 \%$ of healthy patients and in $70 \%$ of patients with impaired perception, such as alcoholics, drug users, epileptics. The pathogenesis of ventilatorassociated pneumonia (VAP) involves the aspiration of bacteria and yeast from the oropharynx to the lung, in addition to host immunosuppression, which makes the destruction of bacteria, resulting in the development of pulmonary infection [1]. The major respiratory pathogens isolated from mechanically ventilated patients include Staphylococcus aureus, Pseudomonas aeruginosa, Acinetobacter baumannii, enteric species and yeasts of the genus Candida. Studies have shown that the dental, subgingival and oral biofilms are frequently colonized by these pathogens [2]. In a study conducted by Heo et al. [3] it was observed that microorganisms from the dental biofilm of mechanically ventilated hospitalized patients were genetically identical to the pathogens of bronchoscopic cultures of the same patient. These findings suggest that the dental biofilm may be an important reservoir of respiratory pathogens that cause pneumonia associated with mechanical ventilation. As a consequence there is a higher cost of the hospitals due to a longer stay of the patient. These complications can cause the patient to develop bacteremia or sepsis, as these pathogens are resistant to many antimicrobials, which could be fatal. Acinetobacter and Candida species are important pathogens associated with nosocomial infection since they are able to form biofilm in medical devices. Microrganisms that make up biofilms exhibit greater resistance to antimicrobial. A. baumannii may be present in oral biofilms, which may act as a reservoir for pneumonia and chronic obstructive pulmonary disease. Subgingival colonization by $A$. baumannii increases the risk of refractory periodontitis. The presence of respiratory pathogens establishes the oral microbiota as an extra-hospital reservoir, and aerolization of these bacteria in the lower respiratory tract can cause pneumonia and chronic obstructive pulmonary disease [1]. Combined with its ability to form biofilms on biotic and abiotic surfaces, the organism has an ability to persist in medical environments, making it especially dangerous for compromised immune hospital patients [4]

For a long time the genus Acinetobacter was considered an opportunistic agent of low pathogenicity. However, a number of virulence factors have been described that make it possible to survive in the hospital setting and the ability to cause disease, particularly in debilitated patients [5]. The virulence factors that allow the survival and adaptation of this agent to the hospital environment include: the ability to capture iron from the environment, thus surviving in conditions of iron deficiency, resistance to drying, production of a polysaccharide capsule, ability to adhere to Different surfaces by the formation of biofilms, and adherence to the cells of the respiratory epithelium through fimbriae [6].

Thus, the oral cavity of ICU patients may serve as an important reservoir for respiratory pathogens associated with nosocomial pneumonia. In view of this, it is necessary to propose new approaches for the control of these pathogens in the oral cavity should be considered in the prevention of nosocomial pneumonia, especially in ICU patients.

\section{References}

1. Scannapieco FA, Yu J, Raghavendran K, Vacanti A, Owens SI, et al. (2009) A randomized trial of chlorhexidine gluconate on oral bacterial pathogens in mechanically ventilated patients. Crit Care 13: R117.

2. Ewan VC, Sails AD, Walls AW, Rushton S, Newton JL (2015) Dental and microbiological risk factors for hospital-acquired pneumonia in nonventilated older patients. PLoS One 29: e0123622.

3. Heo SM, Haase EM, Lesse AJ, Gill SR, Scannapieco FA (2008) Genetic relationships between respiratory pathogens isolated from dental plaque and bronchoalveolar lavage fluid from patients in the intensive care unit undergoing mechanical ventilation. Clin Infect Dis 15: 1562-1570.

4. Gaddy JA, Tomaras AP, Actis LA (2009) The Acinetobacter baumannii 19606 OmpA protein plays a role in biofilm formation on abiotic surfaces and in the interaction of this pathogen with eukaryotic cells. Infect Immun 77: 3150-3160.

5. Kanafani ZA, Perfect JR (2008) Antimicrobial resistance: resistance to antifungal agents: mechanisms and clinical impact. Clin Infect Dis 1: $120-128$.

6. Lee WN, Kang IJ, Lee CH (2006) Factors affecting filtration characteristics in membrane-coupled moving bed biofilm reactor. Water Res 40: 1827-1835. 